\title{
DEFINIRANJE DRŽAVLJANSKOG KORPUSA NA HRVATSKO-SLAVONSKOM PODRUČJU U KRALJEVINI SHS/JUGOSLAVIJI
}

\author{
Doc. dr. sc. Ivan Kosnica*
}

\author{
UDK 342.71:94(497.5-3 Slavonija) \\ https://doi.org/10.30925/zpfsr.39.2.4 \\ Ur.: 24. studenoga 2017. \\ Pr.: 23. ožujka 2018. \\ Izvorni znanstveni rad
}

\begin{abstract}
Sažetak
Predmet rada je, tzv. početno određenje državljanskog korpusa na hrvatskoslavonskom području u Kraljevini SHS/Jugoslaviji. S obzirom na primjetan nedostatak relevantnih istraživanja navedene problematike, autor je proveo vrlo opsežno arhivsko istraživanje odgovarajućih arhivskih fondova dostupnih $u$ Hrvatskom državnom arhivu. Na temelju provedenog istraživanja autor u radu izlaže nekoliko teza. Prva je teza da je odmah po formiranju Kraljevine SHS važio sustav prema kojem su državljani bili svi zavičajnici hrvatsko-slavonskih općina. U nastavku rada autor argumentira tezu da su mirovni ugovori bitno promijenili dotadašnji sustav definiranja državljana na način da su negirali značaj zavičajnosti za utvrđivanje državljanstva ukoliko je stečena nakon 1. siječnja 1910. godine. Autorova je teza da su odredbe mirovnih ugovora kao $i$ restriktivan sustav stjecanja zavičajnosti koji je bio karakterističan za Hrvatsku i Slavoniju u razdoblju do 1918. godine omogućili vlastima Kraljevine SHS provođenje svojevrsnog probira poželjnih državljana te negiranje državljanstva određenom broju doseljenika iz Ugarske. Autor nadalje ocjenjuje da su svojevrsna stabilizacija sustava kao i šire definiranje državljanskog korpusa provedeni tek Zakonom o državljanstvu iz 1928. godine, no uz naglašenu primjenu etničkih kriterija.
\end{abstract}

Ključne riječi: utvrđivanje, državljanstvo, hrvatsko-slavonsko područje, Kraljevina SHS, Kraljevina Jugoslavija.

\section{1. $U V O D^{1}$}

Predmet rada je problematika, tzv. početnog određenja državljanskog korpusa na hrvatsko-slavonskom području u Kraljevini SHS/Jugoslaviji u razdoblju od nastanka

* Dr. sc. Ivan Kosnica, docent Pravnog fakulteta Sveučilišta u Zagrebu; ivan.kosnica@pravo.hr.

1 Rad je nastao kao rezultat istraživanja na Znanstvenoistraživačkom projektu Pravnog fakulteta Sveučilišta u Zagrebu. 
države 1918. do njene okupacije 1941. godine. ${ }^{2}$ Osnovno je istraživačko pitanje koga su državne vlasti i temeljem kojih kriterija smatrale za državljanina Kraljevine SHS/ Jugoslavije na hrvatsko-slavonskom području te jesu li i u kojoj mjeri u promatranom razdoblju vršene promjene i prilagodbe kriterija kojima je definiran državljanski korpus.

Osnovni poticaj za istraživanje navedene problematike nalazimo u činjenici da cjelovita pravnopovijesna analiza navedenog problema još uvijek nije izrađena. Dodatni poticaj jest konstatacija uglednog profesora zagrebačkog Pravnog fakulteta Ladislava Polića, vrsnog poznavatelja hrvatskoga javnog prava, na Drugom kongresu pravnika Kraljevine SHS 1926. godine o tomu da nije potpuno jasno koga su vlasti Kraljevine SHS u prvim poslijeratnim godinama smatrale državljaninom. ${ }^{3}$ Poticaj za istraživanje je i činjenica da zakon o državljanstvu nije donesen punih deset godina te činjenica da je problematika, tzv. početnog određenja državljanskog korpusa u pravilu vrlo važan vid državljanskog prava u trenucima osnivanja novih država, što je i bio slučaj i s Kraljevinom SHS/Jugoslavijom. Konačno, poticajna je i relevantnost teme $\mathrm{u}$ širem europskom kontekstu. ${ }^{4}$

Rad je strukturiran na način da se uvodno daju osnovne napomene o definiranju državljanskog korpusa u Hrvatskoj i Slavoniji u razdoblju do 1918. godine. Nakon toga se daju napomene o osnovnim obilježjima koncepta državljanstva na hrvatskoslavonskom području u Kraljevini SHS/Jugoslaviji te o važnosti državljanstva u pravnom sustavu. Ovo je poglavlje važno za širu kontekstualizaciju državljanstva te za razumijevanje motivacije brojnih osoba koje su nastojale ishoditi priznanje državljanstva Kraljevine SHS/Jugoslavije. U nastavku se izlažu osnovni kriteriji koji su služili vlastima za definiranje državljanskog korpusa u razdoblju od formiranja Kraljevine SHS do stupanja mirovnih ugovora na snagu te zatim od stupanja na snagu mirovnih ugovora do stupanja na snagu Zakona o državljanstvu 1928. Nakon toga se analiziraju neki tipični slučajevi utvrđivanja državljanstva u razdoblju do 1928. godine. U zadnjem dijelu rada analiziraju se odredbe Zakona o državljanstvu iz 1928. godine bitne za definiranje državljanskog korpusa te primjena navedenih odredbi u praksi.

U sklopu istraživanja analizirali smo relevantne propise, komentare zakona, ostalu relevantnu literaturu te također u velikoj mjeri upravnu praksu na temelju arhivskih fondova dostupnih u Hrvatskom državnom arhivu. U sklopu arhivskog istraživanja pretražili smo fond Odjeljenja za unutarnje poslove Pokrajinske uprave za

2 Rad se ne bavi stjecanjem državljanstva. O razlici između, tzv. početnog utvrđivanja korpusa državljana i stjecanja državljanstva vidi: Omejec, Jasna. Initial Citizenry of the Republic of Croatia at the Time of the Dissolution of Legal Ties with the SFRY, and Acquisition and Termination of Croatian Citizenship, Croatian Critical Law Review, vol. 3 (1998), br. 1-2., str. 112.

3 Polić, Ladislav. Pitanje državljanstva, u: Dolenc, Metod i Sajovic, Rudolf. Spomenica na Drugi kongres pravnika Kraljevine Srba, Hrvata i Slovenaca u Ljubljani od 9. do 11. septembra 1926. godine, Društvo „Pravnik“ u Ljubljani, Ljubljana, 1927., str. 210.-211.

4 Za europski kontekst vidi primjerice: Motta, Giuseppe. Less than Nations: Central-Eastern European Minorities after WWI, Volume I, Cambridge Scholars Publishing, Newcastle upon Tyne, 2013., str. 369.-379. 
Hrvatsku i Slavoniju, fond Velikog župana Zagrebačke oblasti, fond Savske banovine upravnog odjeljenja, Zbirku personalija Banovine Hrvatske koja sadrži vrijedne dosjee i za razdoblje do 1918. godine te fond upravnog odjeljenja Banske vlade Banovine Hrvatske.

\section{OSNOVNE NAPOMENE O UTVRDIVANJU I DOKAZIVANJU DRZ̆AVLJANSTVA U HRVATSKOJ I SLAVONIJI DO 1918. GODINE}

U Hrvatskoj i Slavoniji u građanskom razdoblju sve do stupanja na snagu Zakona o stjecanju i gubitku ugarskog državljanstva 1880. godine državljanstvo je utvrđivano na temelju zavičajnosti. ${ }^{5}$ Pojedinci su stoga državljanstvo dokazivali posredno, dokazivanjem zavičajnosti, a u slučaju spora o državljanstvu, spor je u osnovi rješavan primjenom pravila zavičajnog prava.

Osnovni razlog za primjenu toga modela treba tražiti u nepostojanju cjelovitih i sustavnih pravila o državljanstvu, posebno odredbi koje bi mogle biti korištene za, tzv. početno određenje državljanskog korpusa. ${ }^{6}$ Dodatni razlog zasigurno je i taj da su općine bile te koje su vodile imenike zavičajnika, dok službeni popisi državljana nisu postojali.

Bitne promjene u sustavu utvrđivanja državljanstva dogodile su se 1880. godine stupanjem na snagu Zakona o stjecanju i gubitku ugarskog državljanstva. ${ }^{7}$ Taj je zakon sadržavao bitnu odredbu za temeljno određivanje državljanskog korpusa i to tako da je zakonom propisana oboriva presumpcija ugarskog državljanstva svih rođenih, nađenih, odgojenih i othranjenih u zemljama ugarske krune (čl. 19.). Ovo pravno pravilo, kao i čitav sustav novih pravila o državljanstvu, bitno su stabilizirali sustav utvrđivanja državljanstva učinivši ga relativno neovisnim o pravilima zavičajnog prava. ${ }^{8}$ Naime, ako je osoba mogla temeljem izvatka iz matice dokazati rođenje na teritoriju zemalja ugarske krune, presumirano je njeno ugarsko-hrvatsko državljanstvo, čime je spor u načelu gubio značaj spora o državljanstvu. Iako je pravilo o ius soli omogućilo hrvatsko-slavonskim upravnim vlastima na čelu sa Zemaljskom vladom da u nizu slučajeva, utvrde državljanstvo i bez zavičajnosti, ipak je zbog činjenice da su imenici zavičajnika bili jedine službene evidencije o javnopravnom statusu, utvrđivanje zavičajnosti bilo iznimno važno. ${ }^{9}$ Tek je utvrđivanjem zavičajnosti javnopravni status osobe bio nedvojbeno utvrđen te je ona mogla ishoditi domovnicu koja joj je bila

5 Kosnica, Ivan. Utvrđivanje državljanstva u Hrvatskoj i Slavoniji 1849. - 1880., Zbornik radova Pravnog fakulteta u Splitu, god. 51., 3/2014., str. 702.

6 Ibid., str. 700.

7 Zakonski članak L.:1879. zajedničkoga hrvatsko-ugarskoga sabora o stečenju i gubitku ugarskoga državljanstva, obljavljeno u: Sbornik zakonah i naredabah valjanih za kraljevinu Hrvatsku i Slavoniju, komad VII., 1880. O postupku donošenja zakona vidi više u: Varga, Norbert. The Framing of the First Hungarian Citizenship Law (Act 50 of 1879) and the Acquisition of Citizenship, Hungarian Studies, vol. 18 (2004), br. 2., str. 128.-139.

8 Kosnica, Utvrđivanje (...), op. cit., str. 710.

9 Za primjer utvrđivanja državljanstva neovisno o zavičajnosti vidi: Kosnica, Ivan. Citizenship in Croatia-Slavonia during the First World War, Journal on European History of Law, 8 (2017), 1, str. 62 . 
nužna za ostvarivanje niza građanskih, političkih pa i socijalnih prava. Slijedom navedenoga, možemo konstatirati da se sve do 1918. godine državljanstvo u praksi i dalje dokazivalo posredno, dokazivanjem zavičajnosti odgovarajućom domovnicom. Ključni pak propis kojim je utvrđivana zavičajnost ugarsko-hrvatskih državljana u Hrvatskoj i Slavoniji, bio je Zakon o uređenju zavičajnih odnosa u Hrvatskoj i Slavoniji iz 1880. godine. ${ }^{10}$

\section{DRZ̆AVLJANSTVO NA HRVATSKO-SLAVONSKOM PODRUC̆JU U KRALJEVINI SHS/JUGOSLAVIJI: BITNA OBILJEŽJA I ZNAČAJ}

Raskid državnopravnih veza između Kraljevine Hrvatske, Slavonije i Dalmacije i ostatka Austro-Ugarske Monarhije 29. listopada 1918. godine značio je ujedno i raskid s dotadašnjim konceptom jedinstvenog državljanstva za sve zemlje ugarske krune. ${ }^{11}$ Od tada pa sve do ujedinjenja Države SHS s Kraljevinom Srbijom i Crnom Gorom u Kraljevinu SHS 1. prosinca 1918. godine, javnopravni status stanovništva u Hrvatskoj i Slavoniji bio je određen pripadnošću Državi SHS. Ta pripadnost zbog kratkog trajanja te države nije regulirana posebnim zakonom. Ipak, u prilog njenoj važnosti u pravnom sustavu govori činjenica da su vlasti Države SHS donosile propise koji su sadržavali pretpostavku pripadnosti Državi SHS kao temeljnu za ostvarivanje prava. ${ }^{12}$ Ujedinjenjem Države SHS i Kraljevine Srbije i Crne Gore u jednu državu Kraljevinu SHS 1. prosinca 1918. godine nastalo je jedno državljanstvo Kraljevine SHS. Vidovdanskim ustavom potvrđen je koncept jednog državljanstva za čitavu Kraljevinu (čl. 4.), a isto rješenje sadržano je i u Zakonu o državljanstvu Kraljevine SHS iz 1928. godine te u Oktroiranom ustavu Kraljevine Jugoslavije iz 1931. godine (čl. 4.). ${ }^{13}$

Osim državljanstvom, u Hrvatskoj i Slavoniji u razdoblju do 1918. godine

10 Zakon od 30. travnja 1880. o uređenju zavičajnih odnosa u kraljevinama Hrvatskoj i Slavoniji, Sbornik zakonah i naredabah valjanih za kraljevinu Hrvatsku i Slavoniju, komad IX., 1880. Za komentar zakona vidi: Mutavdjić, Koloman. Zavičajno pravo: Zakon od 30. travnja 1880. ob uređenju zavičajnih odnošaja u kraljevinah Hrvatskoj i Slavoniji i prijašnji propisi o stečenju $i$ gubitku zavičajnoga prava, Naklada knjižare Lav. Hartmana (Kugli i Deutsch), Zagreb, 1894. str. 9.-208. Za širu kontekstualizaciju prava zavičajnosti u hrvatsko-slavonskom pravnom poretku vidi: Čepulo, Dalibor. Pravo hrvatske zavičajnosti i pitanje hrvatskog i ugarskog državljanstva 1868-1918 - pravni i politički vidovi i poredbena motrišta, Zbornik Pravnog fakulteta u Zagrebu, vol. 49 (1999), br. 6., str. 811.-822.

11 Prema čl. 1. Zakonskog članka L.:1879. zajedničkoga hrvatsko-ugarskoga sabora o stečenju i gubitku ugarskoga državljanstva državljanstvo je bilo jedno za čitavu ugarsku polovicu AustroUgarske Monarhije.

12 Tako je Narodno vijeće Države SHS propisalo pripadništvo državi SHS kao temeljnu pretpostavku za namještenje učitelja. Vidi čl. 3. Naredbe predsjedništva Narodnog Vijeća Slovenaca, Hrvata i Srba od 12. studenoga 1918., br. 33443, objavljena u: Zbornik zakona i naredaba valjanih za Hrvatsku i Slavoniju, komad XVI, 1918.

13 Ustav Kraljevine Srba, Hrvata i Slovenaca, obnarodovan u br. 142a, Službenih novina na Vidovdan 28. juna 1921. god. u Beogradu, Državna štamparija Kraljevine Srba, Hrvata i Slovenaca, Beograd, 1926. Zakon o državljanstvu Kraljevine Srba, Hrvata i Slovenaca, Službene novine, broj 254/1928. Ustav Kraljevine Jugoslavije, obnarodovan u Službenim novinama 3. rujna 1931., Tisak i naklada knjižare St. Kugli, Zagreb, 1931. 
javnopravni status osoba bio je bitno određen i hrvatsko-slavonskom pripadnošću. ${ }^{14}$ Ulaskom Hrvatske i Slavonije u sklop Kraljevine SHS navedena pripadnost prestala je biti važna. Na tom tragu je Zemaljska vlada za Hrvatsku i Slavoniju već u svibnju 1919. godine izdala naredbu iz koje je jasno vidljivo da posebne zemaljske pripadnosti nisu više odlučne za javnopravni status državljana. ${ }^{15}$ Do svojevrsnog „oživljavanja“ zemaljske pripadnosti došlo je tek za vrijeme Banovine Hrvatske kad je uz jugoslavensko državljanstvo uspostavljena i pripadnost Banovini Hrvatskoj. ${ }^{16}$

Stjecanje i gubitak državljanstva na hrvatsko-slavonskom području, kao u ostalom i na drugim područjima Kraljevine SHS, regulirali su i dalje propisi doneseni u razdoblju do 1918. godine. ${ }^{17} \mathrm{Na}$ hrvatsko-slavonskom pravnom području na snazi je stoga i dalje bio Zakon o stjecanju i gubitku ugarskog državljanstva iz 1879. godine te je nastavio važiti i Zakon o uređenju zavičajnih odnosa iz 1880. godine. Pravni partikularizam u državljanskom pravu dokinut je tek 1928. godine, kad je stupanjem na snagu Zakona o državljanstvu Kraljevine SHS prestao Zakon o državljanstvu iz 1879. godine (čll. 61.).

U promatranom razdoblju državljanstvo je bilo važna pretpostavka prava i obveza. Provedena analiza važnosti državljanstva kao osnove biračkog prava pokazuje da je ono bilo bitna pretpostavka aktivnog i pasivnog biračkog prava. Pritom treba imati u vidu da je odmah po završetku rata primjetna konkurencija državljanstva i etničkog kriterija kao temeljnih pretpostavki biračkog prava. Tako je, primjerice, još u Državi SHS Narodno vijeće Države SHS izdalo naputak prema kojem članovi mjesnih odbora "mogu biti samo Srbi, Hrvati i Slovenci te ostali Slaveni, ali Nijemci i Mađari nikako". ${ }^{18}$ Vrlo specifično uređenje sadržavao je i izborni zakon za Ustavotvornu skupštinu iz 1920. godine i to na način da su kao državljani s biračkim pravom određeni i svi ,po plemenu i jeziku Slaveni koji su se do početka sastavljanja biračkih spiskova stalno nastanili u kojoj našozemskoj općini“, neovisno o pretpostavci državljanstva, dok je biračko pravo negirano državljanima s pravom opcije. ${ }^{19}$ Korištenje državljanstva i etničkoga kriterija kao konkurentskih osnova biračkog prava ipak nije bilo dosljedno provedeno, pa su tako propisi o lokalnim izborima za hrvatsko-slavonsko područje iz 1919. godine sadržavali samo kriterij državljanstva. ${ }^{20}$ Državljanstvo kao conditio

14 Za važnost hrvatsko-slavonske pripadnosti za javnopravni status osoba u Hrvatskoj i Slavoniji od 1868. do 1918. godine vidi: Kosnica, Ivan. Hrvatsko-slavonska pripadnost u Hrvatskoj i Slavoniji u nagodbenom razdoblju, Hrvatska i komparativna javna uprava - Croatian and Comparative Public Administration, vol. 14. (2014), br. 2., str. 470.-485.

15 HR HDA, Pokrajinska uprava za Hrvatsku i Slavoniju u Zagrebu, Odjeljenje za unutarnje poslove (u nastavku: HDA PU HiS OUP), Sv. V-2 62501/1922.

16 Andrassy, Juraj. Novo ustavno uređenje Hrvatske, Mjesečnik: glasilo hrvatskoga pravničkoga društva, Zagreb, 1940., str. 230.

17 Štiks, Igor. Nations and Citizens in Yugoslavia and the Post-Yugoslav States: One Hundred Years of Citizenship, Bloomsbury Academic, London-New York, 2015., str. 32.-33.

18 Goldstein, Ivo. Hrvatska 1918.-2008., EPH Liber, Zagreb, 2008., str. 20.

19 Polić, Ladislav. O pravnim osnovima budućeg izbornoga reda, Mjesečnik: glasilo pravničkoga društva, br. 2., 1922., str. 51. Engelsfeld, Neda. Povijest hrvatske države i prava: razdoblje od 18. do 20. stoljeća, Pravni fakultet, Zagreb, 1999., str. 339.

20 Usp. čl. 1. Uredbe o izboru gradskih zastupstva za gradove Hrvatske i Slavonije, u: Zbornik zakona i naredaba valjanih za Hrvatsku i Slavoniju, godina 1919., Kr. zemaljska tiskara, 
sine qua non biračkog prava propisali su i Ustav Kraljevine SHS od 28. lipnja 1921. godine (čl. 70.) te Ustav Kraljevine Jugoslavije (čl. 55.), dok etnički kriterij nije više navođen.

Državljanstvo je bilo i temeljna pretpostavka za zapošljavanje u državnoj upravi. Tako je već početkom 1919. godine na hrvatsko-slavonskom području objavljen niz natječaja za radna mjesta u kojima je kao nužna pretpostavka zaposlenja navedeno državljanstvo Kraljevine SHS. ${ }^{21}$ Također, državljanstvo je bilo bitna pretpostavka za namještenje u gradskim i općinskim službama. ${ }^{22}$ Važnost državljanstva kao pretpostavke za obnašanje javnih službi konačno je konstitucionaliziran 28. lipnja 1921. godine Ustavom Kraljevine SHS (čl. 19.). Navedeno načelo sadržano je i u kasnijim propisima, pa tako primjerice u Zakonu o činovnicima iz 1923. godine, Zakonu o činovnicima iz 1931. godine te također i u Ustavu Kraljevine Jugoslavije iz 1931. godine (čl. 19.). ${ }^{23} \mathrm{U}$ određenoj mjeri, slično kao i kod biračkog prava, po nastanku nove države vidljivo je ispreplitanje državljanstva i etničke pripadnosti kao osnove zapošljavanja u državnoj službi. Tako je, primjerice, Ustavom Kraljevine SHS određeno da državnu službu mogu obnašati svi državljani po rodu te naturalizirani državljani ako su etnički Srbi, Hrvati i Slovenci. U slučaju pripadnosti nekoj drugoj etničkoj grupi tražio se protek od barem deset godina od naturalizacije (čl. 19.). ${ }^{24}$ Ustav Kraljevine Jugoslavije nije sadržavao sličnu odredbu. Konačno, državljanstvo je bilo i nužna pretpostavka koju je trebalo dokazati u postupku izdavanja putnih isprava. ${ }^{25}$ Također, državljanstvo je bilo i temeljna pretpostavka vojne obveze, iako se ponekad moglo dogoditi da vojnu obvezu izvrše i stranci. ${ }^{26}$

Zagreb, 1920., str. 267.-271. Usp. čl. 1. Uredbe o izboru općinskih odbora za upravne općine Hrvatske i Slavonije, u: Zbornik zakona i naredaba valjanih za Hrvatsku i Slavoniju, godina 1919., Kr. zemaljska tiskara, Zagreb, 1920., str. 274.-280.

21 Vidi natječaj za popunjavanje 15 radnih mjesta kod financijalnog ravnateljstva u Zagrebu. Narodne novine, br. 9., 13. siječnja 1919., Zagreb, str. 2. Vidi i natječaj za popunjavanje mjesta podvornika kod financijalnog ravnateljstva u Bjelovaru. Narodne novine, br. 23., 29. siječnja 1919., Zagreb, str. 1.

22 Vidi natječaj koji je raspisalo gradsko poglavarstvo u Petrovaradinu za popunjavanje radnog mjesta općinskog blagajnika. Narodne novine, br. 25., 31. siječnja 1919., Zagreb, str. 1. Vidi i natječaj koji je raspisalo Gradsko poglavarstvo grada Zagreba za mjesto školskog liječnika. Narodne novine, br. 27., 3. veljače 1919., Zagreb, str. 1.

23 Usp. čl. 2. Zakona o činovnicima i ostalim državnim službenicima građanskog reda iz 1923. godine. Zakon s komentarom u: Cavalieri, Celso. Propisi o činovnicima i ostalim državnim službenicima građanskog reda, Vlastita naklada, Zagreb, 1926., str. 1-3. Usp. čl. 2. Zakona o činovnicima iz 1931. godine. Zakon s komentarom u: Cavalieri, Celzije. Tumač zakona o činovnicima s naročitim osvrtom na zakon o državnom saobraćajnom osoblju, Vlastita naklada, Zagreb 1931., str. 8.-10.

24 Iznimka od pravila zabrane obnašanja državne službe bila je moguća samo po odluci Državnog savjeta koja je trebala biti donesena na prijedlog nadležnog ministra. Usp. čl. 19. Ustava Kraljevine SHS.

25 Tipične slučajeve utvrđivanja državljanstva u povodu izdavanja putne isprave vidi u: HR. Hrvatski državni arhiv, Savska banovina, upravno odjeljenje, fond 144 (u nastavku: HDA SB UO), kutija 1101, godina 1935, 32305/1935 (izjava banske uprave Savske banovine o državljanstvu Geček Tome). HDA SB UO, kutija 1102, godina 1935 (izjava banske uprave Savske banovine o državljanstvu Ivana Novaka).

26 Jedan takav primjer vidi u: HR HDA Zagrebačka oblast, Veliki župan, fond 141 (u nastavku: 


\section{DEFINIRANJE DRZ̆AVLJANSKOG KORPUSA U RAZDOBLJU DO MIROVNIH UGOVORA}

Odmah po nastanku Kraljevine SHS u praksi je primjenjivano načelo prema kojem su državljani Kraljevine SHS na hrvatsko-slavonskom području svi koji su zavičajni u nekoj od hrvatsko-slavonskih općina. Zavičajnost je kao način utvrđivanja državljanstva došla do izražaja i u prijedlogu Zakona o državljanstvu Kraljevine SHS iz 1919. godine, koji ipak nikad nije usvojen u Privremenom narodnom predstavništvu, a kojim je određeno da su na području Hrvatske i Slavonije državljani svi koji su 1. prosinca 1918. godine imali zavičajnost u Hrvatskoj i Slavoniji. ${ }^{27}$

Da je zavičajnost bila osnovni način određenja državljanskog korpusa vidljivo je i iz natječaja koji su objavljivani u prvoj polovici 1919. godine, a odnosili su se na zapošljavanje u državnoj upravi, gradovima i općinama. Podnositelji molbi su u pravilu uz zamolbu trebali priložiti i domovnicu kao potvrdu o zavičajnosti. Tako je prema natječaju financijskog ravnateljstva u Zagrebu od 13. siječnja 1919. godine podnositelj trebao dokazati svoju domovinu, što je u pravilu podrazumijevalo dokazivanje domovnicom. ${ }^{28}$ U natječaju od 31. siječnja 1919. godine, koji je raspisalo gradsko poglavarstvo u Petrovaradinu, za mjesto općinskog blagajnika među uvjetima natječaja navodi se i da interesent mora dokazati zavičajnost "koje općine u Jugoslavenskoj državi SHS". ${ }^{29}$ Sličan primjer je i natječaj koji je raspisao grad Zagreb za zapošljavanje školskoga liječnika u kojem se također navodi da podnositelj činjenicu pripadnosti Kraljevini treba dokazati domovnicom. ${ }^{30}$

\section{UTJECAJ MIROVNIH UGOVORA NA, TZV. POČETNO ODREĐENJE DRZ̆AVLJANSKOGA KORPUSA}

Ključan događaj koji je označio promjenu u pogledu, tzv. početnog definiranja državljanskoga korpusa na hrvatsko-slavonskom području bilo je sklapanje mirovnog ugovora s Ugarskom u Trianonu. Temeljni kriterij za definiranje državljanskoga korpusa propisan tim ugovorom, a koji je bio sadržan i u mirovnom ugovoru s Austrijom, bio je kriterij prema kojem su državljanstvo Kraljevine SHS stekli svi koji su bili zavičajni na teritoriju Kraljevine SHS do 1. siječnja 1910. godine te su svoju zavičajnost zadržali do stupanja na snagu mirovnog ugovora odnosno do 26. lipnja 1921. godine. ${ }^{31}$ Pored toga, mirovni ugovor s Ugarskom, kao i mirovni ugovor

HDA ZO VŽ), IV-1, 45574/1926.

27 Polić, Pitanje (...), op. cit., str. 211. Vidi i: Engelsfeld, Neda. Prvi parlament Kraljevstva Srba, Hrvata i Slovenaca - Privremeno narodno predstavništvo, Globus, Zagreb, 1989., str. 132.

28 Narodne novine, br. 9., 13. siječnja 1919., Zagreb, str. 2.

29 Narodne novine, br. 25., 31. siječnja 1919., Zagreb, str. 1.

30 Vidi natječaj u: Narodne novine, br. 27., 3. veljače 1919., Zagreb, str. 1.

31 Usp. čl. 61. i 62. Ugovora o miru s Ugarskom. Usp. čl. 1. Naredbe ministra unutrašnjih djela o postupanju pri stjecanju i gubitku državljanstva Kraljevine SHS putem opcije i molbe od 30. kolovoza 1921. godine. Usp. čl. 70. i 76. Ugovora o miru s Austrijom. Usp. čl. 1. Kraljeve uredbe o stjecanju i gubitku državljanstva Kraljevine SHS putem opcije i molbe od 25. novembra 1920. godine. Relevantan tekst mirovnih ugovora te tekst naredbe ministra unutrašnjih djela i kraljeve 
s Austrijom, sadržavao je i detaljna pravila o opciji čime je jedan dio državljana, u pravilu se radilo o pripadnicima manjina, stavljen u status „državljana na čekanju“. Naglašavanje etničke pripadnosti u mirovnim ugovorima kao bitne za određenje državljanstva rezultiralo je pak dodatnim tenzijama te je ujedno dodatno potenciralo etničku određenost državljanstva. ${ }^{32}$ Naposljetku, valja spomenuti i sporazume o državljanstvu koje su vlasti Kraljevine SHS sklopile s Kraljevinom Italijom, a koji su, iako ne spadaju u sklop klasičnih mirovnih ugovora, znatno utjecali na problematiku utvrđivanja državljanstva u zapadnom dijelu Kraljevine SHS. Ovi su sporazumi mogli biti važni i u postupcima utvrđivanja državljanstva na hrvatsko-slavonskom području, osobito s obzirom na činjenicu da je određen broj Hrvata i Slovenaca s okupiranih područja prebjegao upravo na to područje Kraljevine SHS. Prema sporazumu o utvrđivanju državljanstva osoba s riječkog područja, temeljno pravilo za utvrđivanje državljanstva bilo je boravište na dan 3. studenoga 1918., dok je tek podredno korišten i kriterij zavičajnosti. ${ }^{33}$

Odredbe mirovnih ugovora kao i odredbe sporazuma sklopljenih s Kraljevinom Italijom relativizirale su važnost zavičajnosti kao načina dokazivanja državljanstva te je sukladno tomu relativiziran i značaj potvrda o zavičajnosti (domovnica) za dokazivanje državljanstva. Naime, činjenica da je osoba imala domovnicu još uvijek nije bila dovoljan dokaz državljanstva Kraljevine SHS, budući da se, primjerice, moglo raditi o osobi koja je zavičajnost stekla nakon 1. siječnja 1910. godine ili se moglo raditi o osobi s pravom opcije za drugu državu. Dodatan razlog za nepovjerenje prema dokaznoj snazi domovnica bila je i činjenica što su u praksi uočene brojne nepravilnosti dodjele zavičajnosti stranim državljanima te nezakoniti upisi u imenike zavičajnika. ${ }^{34}$ Zbog svega su, u slučaju indicija da je osoba strani državljanin, upravne vlasti bile dužne voditi upravni postupak radi utvrđivanja državljanstva. Pritom su u nizu slučajeva upravne vlasti osporile domovnice izdane po općinama te su odbile priznati državljanstvo osobama za koje su utvrdile da su strani državljani. Dobar primjer jednog takvog propitivanja dokazne snage domovnice predmet je vođen pred Pokrajinskom upravom za Hrvatsku i Slavoniju tijekom 1922. godine, u kojem je s obzirom na sumnju u pogledu državljanstva vođen postupak utvrđivanja državljanstva Aleksandra Roknića, odvjetnika u Mitrovici, Mije Kokotnića iz Zagreba i Lazara Baćanija iz općine Sv. Petar Orehovec pokraj Križevaca. Sva trojica imala su domovnice, no neovisno o tomu Pokrajinska uprava je tražila od podređenih upravnih vlasti izvještaj o tomu od kad su te osobe zavičajnici te na kojem zakonskom temelju

uredbe vidi u: Pirkmajer, Otomar. Zakon o državljanstvu sa tumačenjem, Izdavačka knjižara Gece Kona, Beograd, 1929., str. 226.-301. Usp. i Čepulo, Dalibor. Prava građana i moderne institucije: Europska i hrvatska pravna tradicija, Pravni fakultet Sveučilišta u Zagrebu, Zagreb, 2003., str. 86.

32 Fahrmeir, Andreas. Citizenship: The Rise and Fall of a Modern Concept, Yale University Press, New Haven and London, 2007., str. 126.

33 Bartulović, Željko. Sušak 1919.-1947.: Državnopravni položaj grada, Pravni fakultet Sveučilišta u Rijeci, Državni arhiv u Rijeci, Adamić, Rijeka, 2004., 78.-79.

34 HDA ZO VŽ, IV-1,13939/1926. U praksi se događalo da su određeni pojedinci primljeni u zavičajnost rješenjem općinskih vlasti, iako s obzirom na odredbe mirovnih ugovora nisu bili i državljani Kraljevine SHS. Zbog toga je kod Velikog župana Zagrebačke oblasti interveniralo i Ministarstvo unutrašnjih djela početkom 1926. godine. Vidi: HDA ZO VŽ, IV-1, 13939/1926. 
su stekle zavičajnost u Hrvatskoj i Slavoniji. U izvještaju upućenom Ministarstvu unutrašnjih poslova Odjeljenju za Hrvatsku i Slavoniju u Beogradu, Pokrajinska uprava za Hrvatsku i Slavoniju konstatirala je da su Aleksandar Roknić i Mijo Kokotnić državljani Kraljevine SHS, dok se provode daljnji izvidi u pogledu državljanstva Lazara Baćanija, rođenog 1867. godine u Križevcima. U posljednjem slučaju sporno je bilo to što su neki članovi obitelji Lazara Baćanija bili zavičajni u Mađarskoj te mu stoga Pokrajinska uprava nije mogla utvrditi državljanstvo Kraljevine SHS. ${ }^{35}$

S obzirom na relativizaciju značaja domovnica za utvrđivanje državljanstva, u praksi je via facti uvedena klauzula odnosno potvrda o državljanstvu koju su izdavale upravne vlasti nakon provedenog postupka utvrđivanja državljanstva. ${ }^{36}$ Sve je pak rezultiralo promjenama u natječajima za radna mjesta u državnoj upravi, gradovima i općinama u kojima je sad izrijekom navođena nužnost podnošenja potvrde o državljanstvu ili, tzv. klauzule o državljanstvu. ${ }^{37}$

Iako je mirovnim ugovorima značaj zavičajnosti relativiziran, u nedostatku drugih evidencija, evidencije o zavičajnicima su i dalje bile temeljna polazišna osnova za utvrđivanje državljanstva. Upravo zbog toga, upravne su vlasti u tom razdoblju obavljale opsežan posao utvrđivanja zavičajnosti te posao sređivanja imenika zavičajnika. ${ }^{38}$ Sređene evidencije zavičajnika trebale su olakšati izdavanje potvrda o državljanstvu. Pritom se s obzirom na jake nadzorne ovlasti upravnih vlasti u čitavom procesu sređivanja imenika zavičajnika, naročito s obzirom na činjenicu da su upravne vlasti pazile da su u imenike upisani samo državljani, ovdje de facto radilo o stvaranju evidencija o državljanstvu. Proces sređivanja evidencija o državljanstvu provođen je, dakle na temelju lokalnih evidencija o zavičajnicima što možemo usporediti sa sličnim razvojem u zapadnoeuropskim zemljama, doduše, u ranom modernom razdoblju te tijekom 19. stoljeća, u kojima je vidljivo snažno oslanjanje središnje države na lokalne vlasti pri evidentiranju državljana. ${ }^{39}$

Na kraju ovoga dijela rada treba još reći da su, osim na temelju odgovarajuće zavičajnosti, pojedinci mogli zahtijevati da im se prizna državljanstvo na temelju

35 HDA PU HiS OUP, Sv. V-2 15991/1922.

36 Vidi primjerice očitovanje Pokrajinske uprave za Hrvatsku i Slavoniju da je Dušan Ogrizović državljanin Kraljevine SHS. HDA PU HiS OUP, Sv. V-2 26927/1922. Vidi također, tzv. „klauzulu na domovnicu“ koju je izdala Pokrajinska uprava za Hrvatsku i Slavoniju 5. srpnja 1922. godine. Tom klauzulom Pokrajinska uprava potvrđuje da je Asdrubale Berger državljanin Kraljevine SHS. Navedena klauzula izdana je nakon izvida gradskog poglavarstva u Zagrebu kojima je potvrđeno da je Berger naturaliziran dekretom Zemaljske vlade 8. studenog 1898., a da je prisegu položio 1. prosinca 1898. godine. HDA PU HiS OUP, sv. V-3 36910/1922.

37 Tako je iz uvjeta natječaja od 17. travnja 1926. godine, koji je raspisalo financijalno ravnateljstvo u Varaždinu za radno mjesto služitelja kod poreznog ureda u Krapini vidljivo da je podnositelj trebao dokazati državljanstvo Kraljevine SHS, te je kao prilog molbi trebao podastrijeti domovnicu "izdanu poslije ujedinjenja u kojoj mora biti izrijekom potvrđeno da je molitelj državljanin kraljevine Srba, Hrvata i Slovenaca" Narodne novine, br. 89., 17. travnja 1926., Zagreb, str. 1.

38 Vidi izvještaje o utvrđivanju zavičajnosti koje su tijekom 1927. godine prvostupanjske upravne vlasti, gradska poglavarstva i srezovi, podnijeli Velikom županu Zagrebačke oblasti u: HDA ZO VŽ, IV-1, 6802/1926.

39 Lucassen, Leo. Between Hobbes and Locke. Gypsies and the limits of the modernization paradigm, Social History, vol. 33 (2008), br. 4., str. 425.-426. 
Zakona o zaštiti manjina koji je Kraljevina SHS prihvatila na Pariškoj mirovnoj konferenciji. ${ }^{40}$ Navedeni zakon je predvidio državljanstvo Kraljevine SHS za sve osobe rođene na teritoriju Kraljevine ako „... se ne mogu pozvati ni na koje drugo državljanstvo po rođenju“ (čl. 6.). ${ }^{41}$ Svrha zakona bila je zaštita pripadnika manjina čiji su državljanstvo i zavičajnost bili nepoznati, odnosno osoba kojima zbog dulje odsutnosti, ponekad i više od 30 godina, prijašnje vlasti nisu priznavale državljanstvo.

\section{UTVR円IVANJE DRZ̆AVLJANSTVA U UPRAVNOJ PRAKSI DO 1928. GODINE}

Nadležna tijela u predmetima utvrđivanja državljanstva za hrvatsko-slavonsko pravno područje odmah po osnutku Kraljevine SHS bila su Ministarstvo unutrašnjih poslova, upravno odjeljenje, odsjek za Hrvatsku i Slavoniju, Zemaljska vlada za Hrvatsku i Slavoniju te županije i kotarevi kao prvostupanjske upravne vlasti. Nakon stupanja na snagu Vidovdanskog ustava, Ministarstvo unutrašnjih poslova, upravno odjeljenje, odsjek za Hrvatsku i Slavoniju zadržalo je vrhovnu nadležnost u postupcima utvrđivanja državljanstva. Uz to tijelo, u Hrvatskoj i Slavoniji umjesto Zemaljske vlade formirana je Pokrajinska uprava za Hrvatsku i Slavoniju. Ta su tijela zajedno sa županijama i od tada srezovima zadržala nadležnost u postupcima utvrđivanja državljanstva. Reforma upravne organizacije naznačena Ustavom iz 1921. godine, prema kojoj su trebale biti ukinute pokrajine i formirane oblasti u punoj je mjeri zaživjela tek početkom $1925 .{ }^{42}$ Od tada su u poslovima utvrđivanja državljanstva bili nadležni Ministarstvo unutrašnjih poslova u Beogradu, veliki župani u oblastima te srezovi kao prvostupanjske upravne vlasti. Pritom su se četiri oblasti više-manje preklapale s dotadašnjim granicama hrvatsko-slavonskog pravnog područja. Bile su to Zagrebačka, Osječka, Primorsko-krajiška i Srijemska oblast.

Pregledom arhivske građe moguće je utvrditi relativno velik broj slučajeva utvrđivanja državljanstva ugarskih naseljenika koji su se naselili u Hrvatskoj i Slavoniji do 1918. godine te su nakon raspada Austro-Ugarske Monarhije tu ostali

40 Prvi sporazum o manjinama, sastavljen na Pariškoj mirovnoj konferenciji, odnosio se na Poljsku da bi zatim sličan sporazum bio proširen i na ostale države nastale na teritorijima Austro-Ugarske Monarhije, pa tako i na Kraljevstvo SHS. Sporazum o manjinama postao je i dio pravnog poretka Grčke, Bugarske i Baltičkih država, no ne i Finske i Italije koje su bile izuzete. Fink, Carole. The Paris Peace Conference and the Question of Minority Rights, Peace \& Change, vol. 21. (1996), br. 3., str. 280. Usp. i: Riga, Liliana i Kennedy James. Tolerant majorities, loyal minorities and „ethnic reversals“: constructing minority rights at Versailles 1919, Nations and Nationalism, vol. 15. (2009), br. 3., str. 462.-463. O sustavu zaštite manjina u razdoblju između Prvog i Drugog svjetskog rata vidi i: Vukas, Budislav. Etničke manjine i međunarodni odnosi, Školska knjiga, Zagreb, 1978., str. 62.-70. Mazur Kumrić, Nives. Europski sustav zaštite prava manjina uz poseban osvrt na Vijeće Europe i Organizaciju za sigurnost i suradnju u Europi, Školska knjiga, Zagreb, 2017., str. 126.-136.

41 Zakon o zaštiti manjina, vidi u: Pirkmajer. op. cit., str. 316.-324.

42 O položaju Zemaljske vlade i Pokrajinske uprave za Hrvatsku i Slavoniju u sustavu vlasti te o tome da su oblasti u punoj mjeri profunkcionirale tek početkom 1925. godine vidi i: Beuc, Ivan. Povijest institucija državne vlasti u Hrvatskoj (1927-1945), Arhiv Hrvatske, Zagreb, 1969., str. 338.-339. 
živjeti. Analiza prakse pokazuje da je brojnim siromašnim doseljenicima iz Ugarske u Hrvatskoj i Slavoniji nakon 1918. godine bilo otežano dokazivanje državljanstva. To zbog toga što mnogi od njih ni nakon dugog boravka nisu stekli zavičajnost. U prilog otežanim mogućnostima integracije govori i činjenica da često ni djeca takvih naseljenika, iako su desetljećima živjela u Hrvatskoj i Slavoniji, nisu priznata za državljane. Ilustrativan je u tom smislu predmet Katona Gjure koji je rođen u Voćinu 1863. godine, te je ujedno bio i vojni obveznik stavljen za općinu Voćin, kojem je Pokrajinska uprava u postupku vođenom 1922. godine odbila priznati zavičajnost i državljanstvo u Hrvatskoj i Slavoniji s obzirom na činjenicu da nije stekao zavičajnost u Hrvatskoj i Slavoniji, ustvrdivši da je po ocu „vlastelinskom birošu“ stekao zavičajnost u Ugarskoj, pritom naglasivši da mu je ugarska općina 1880. godine izdala služinsku knjigu. ${ }^{43}$ Pogrešno bi bilo zaključiti da su vlasti uvijek negirale stjecanje državljanstva doseljenicima iz Ugarske. Na temelju niza slučajeva vidljivo je da su upravne vlasti ponekad i suprotno od stava hrvatsko-slavonskih općina koje su htjele izbjeći plaćanje bolnoopskrbnih troškova priznavale državljanstvo naseljenicima iz Ugarske. Državljanstvo je u pravilu priznavano onda kad su postojali neosporni dokazi da su te osobe stekle zavičajnost u Hrvatskoj i Slavoniji u razdoblju do 1. siječnja 1910. godine. ${ }^{44}$

Specifičnu grupu ugarskih doseljenika činili su službenici zajedničkih ugarskohrvatskih ureda u Hrvatskoj i Slavoniji te zaposlenici na željeznicama. Pritom su ugarski zavičajnici osobito bili brojni na željeznicama. Ilustrativni su u tom smislu zbirni podatci o zaposlenicima na državnim željeznicama 1903. godine. Prema njima u gradu Zagrebu te u županijama zagrebačkoj, bjelovarsko-križevačkoj, varaždinskoj, požeškoj, srijemskoj i modruško-riječkoj (bez virovitičke županije i ličko-krbavske županije) od 2018 zaposlenika na željeznicama, njih 1317 (65,26\%) su bili ugarski zavičajnici. ${ }^{45} \mathrm{U}$ razdoblju do 1918 . godine ti doseljenici, kao i ugarski zavičajnici namješteni u zajedničkim ugarsko-hrvatskim uredima, nisu stjecali zavičajnost $\mathrm{u}$ Hrvatskoj i Slavoniji. To stoga što se prema Zakonu o uređenju zavičajnih odnosa iz 1880. godine zavičajnost u Hrvatskoj i Slavoniji mogla steći samo namještenjem u autonomnu javnu službu. ${ }^{46}$ Te su kategorije osoba stoga nakon raspada AustroUgarske Monarhije s obzirom na stranu zavičajnost postale strani državljani. ${ }^{47}$

Također, vrlo specifičnu grupu slučajeva čine i slučajevi utvrđivanja državljanstva osobama koje su do 1918. godine bile dio društvene i političke elite. Kao vrlo ilustrativan možemo navesti predmet obitelji Gutmann. Spor o državljanstvu obitelji Gutmann započeo je još 1919. godine na inicijativu umirovljenog općinskog bilježnika Ilije Stojšića iz Valpova te Miše Nikolića i drugih iz Osijeka koji su prijavili Zemaljskoj vladi da je općina Valpovo trgovište 29. travnja 1919. godine dodijelila zavičajnost braći Vilmošu, Laciju i Alfredu Gutmannu te da je dodijelila

43 HDA PU HiS OUP, Sv. V-3 21062/1922.

44 Vidi u tom smislu predmet utvrđivanja zavičajnosti i državljanstva Nagy Josipa kojem je općina Čepin 26.6.1894. izdala svjedodžbu o pripadnosti. HDA PU HiS OUP, Sv. V-3 25212/1922.

45 Dobrovšak, Ljiljana. Zaposlenici na željeznicama u Hrvatskoj 1903. godine, Časopis za suvremenu povijest, vol. 40 (2008), br. 2., str. 514.-516.

46 Mutavdjić, op. cit., str. 76.

47 Vidi slučaj Lipovčak. HDA ZO VŽ, IV-1, 6058/1926. 
zavičajnost i trojici činovnika koji su službovali kod Gutmanna. Nakon provedenog postupka Zemaljska vlada je utvrdila da se radilo o nezakonitom postupku primanja u zavičajnost stranih mađarskih državljana te je poništena odluka općinskih vlasti i naloženo je brisanje dotičnih iz imenika zavičajnika. ${ }^{48}$

Osobitost predmeta obitelji Gutmann ogleda se i u činjenici da je usporedno s negiranjem državljanstva braći Vilmošu, Laciju i Alfredu Gutmannu, započela i rasprava o zavičajnosti i državljanstvu četvrtog brata Edmunda Gutmanna koji je umro 1918. godine, a temeljem čije je zavičajnosti njegov sin Artur stekao zavičajnost u općini Valpovo. Bitna razlika između zavičajnosti Edmunda odnosno Artura Gutmanna i ostalih Gutmanna bila je u tomu što se u slučaju Edmunda odnosno njegovog sina Artura nije radilo o stjecanju zavičajnosti u Kraljevini SHS, nego je Edmund Gutmann bio priznat zavičajnikom i tijekom Austro-Ugarske. Iz spisa tako saznajemo da je Edmund Gutmann doselio u Hrvatsku i Slavoniju 1884. godine i da je prije 1898. godine bio upisan u imenik zavičajnika općine Valpovo trgovište te da je tu plaćao općinske poreze, bio unesen u izborne listine te da je vršio sva prava općinskog pripadnika. Zemaljska vlada je u spisu utvrdila da vršenje prava zavičajnika uključujući i biračkog prava na županijskim i saborskim izborima ne znači nužno da je osoba i stekla zavičajnost. Nakon provedenih izvida, što je uključivalo i provjeru urudžbenog zapisnika općine Valpovo za razdoblje od 1884. godine, Zemaljska vlada navodi da nije pronađen zahtjev za stjecanjem zavičajnosti koji bi podnio netko od obitelji Gutmann niti je pronađena prijava namjere naseljenja. Vlada zatim konstatira da je Edmund Gutmann sve vrijeme bio protuzakonito unesen u imenik zavičajnika te je naložila brisanje Edmunda Gutmanna, njegove supruge Albertine i sina Artura iz imenika, kao i poništaj i oduzimanje domovnice izdane Arturu Gutmannu. ${ }^{49}$ Ono što je u slučaju Edmunda Gutmanna značajno, a što ukazuje na restriktivnije tumačenje pravila o zavičajnosti u usporedbi sa stanjem do 1918. godine jest to da mu državljanstvo nije priznato usprkos činjenici što je tijekom Austro-Ugarske Monarhije uživao puna politička prava u Hrvatskoj i Slavoniji.

S obzirom na to da su im vlasti Kraljevine SHS odbile priznati državljanstvo, Gutmanni su od tada boravili u Belišću kao strani, mađarski državljani te im je kao strancima dopušten boravak temeljem rješenja upravnih vlasti. ${ }^{50}$ Neki su članovi obitelji Gutmann ipak naturalizirani, no tek uoči Drugoga svjetskog rata..$^{51}$

Drugi ilustrativan slučaj utvrđivanja državljanstva osobi koja je do 1918. godine bila dio društvene i političke elite je predmet Majlath. U tom predmetu radilo

48 HDA PU HiS OUP, Sv. V-3 18914/1922 (izvještaj od 9.9.1919., br. 39492/1919).

49 HDA PU HiS OUP, Sv. V-3 18914/1922 (izvještaj od 9.9.1919., br. 39492/1919).

50 HR Hrvatski državni arhiv, Zbirka personalija Banovine Hrvatske, fond 890, (u nastavku: HDA Zbirka personalija BH), dosije 32573. HDA Zbirka personalija BH, dosije 32578. HDA Zbirka personalija BH, dosije 32581. HDA Zbirka personalija BH, dosije 32589.

51 Naturalizirani su Viktor (otac Alfred) Gutmann s obitelji potkraj 1938. godine te Ernest (otac Alfred) Gutmann s obitelji potkraj 1940. godine. Vidi HDA Zbirka personalija BH, dosije 32589. Interesantno je da je Banska vlada Banovine Hrvatske Ernestu Gutmannu, njegovoj supruzi Kamili i kćeri Elinor prvotno tijekom 1940. godine ograničila boravak u zemlji na pola godine bez mogućnosti produljenja, da bi ga ipak potraj 1940. godine naturalizirala. HDA Zbirka personalija BH, dosije 32576. HDA Zbirka personalija BH, dosije 25593. 
se o utvrđivanju državljanstva Mađara grofa Ladislava Majlatha, veleposjednika u Slavoniji koji je nastojao ishoditi priznanje državljanstva temeljem stjecanja zavičajnosti u Donjem Miholjcu prije 1. siječnja 1910. godine. Majlathu je općina Donji Miholjac priznala zavičajnost, no kotar je kao prvostupanjska upravna vlast zavičajnost osporio. Nakon toga je županija djelujući u drugom stupnju Majlathu priznala zavičajnost, zatim Pokrajinska uprava poništava odluku županije da bi u konačnici čitav slučaj bio riješen odlukom Ministarstva unutarnjih djela u Beogradu koje je poništilo rješenje Pokrajinske uprave i donijelo odluku o priznanju državljanstva Ladislavu Majlathu. ${ }^{52} \mathrm{Za}$ šire sagledavanje problematike, zasigurno su važni razlozi temeljem kojih su Majlathu upravna tijela priznala odnosno osporavala zavičajnost pa onda i državljanstvo. Ključan razlog na temelju kojeg mu je Pokrajinska uprava odbila priznati državljanstvo bio je taj što Majlath nije stekao zavičajnost u Hrvatskoj i Slavoniji kvalificiranim naseljenjem jer nije izrijekom prijavio namjeru naseljenja općinskim vlastima.$^{53}$ Suprotno tomu, Ministarstvo unutrašnjih djela, rješenjem od 3. studenoga 1923. godine Majlathu je priznalo državljanstvo i to tako što nije uzelo u obzir nedostatak prijave nego je uzimalo kao ključne činjenicu neprekidnog boravka u Donjem Miholjcu od 1892. godine, to da mu je općina Donji Miholjac izdala domovnicu u kojoj se navodi da je Majlath zavičajnik od 1895. godine te argument da je Majlath 1910. godine bio izabran za općinskog odbornika. Odluka o priznanju državljanstva Ladislavu Majlathu temeljila se na činjenici da je stekao zavičajnost do 1. siječnja 1910. godine. ${ }^{54}$ Interesantna je k tomu i pozadina čitavog slučaja koju iščitavamo iz dopisa žitelja Čađavice upućenog Pokrajinskoj vladi. U dopisu od 1. lipnja 1922. godine žitelji Čađavice ističu razloge koji su grofa Majlatha motivirali da traži utvrđenje državljanstva Kraljevine SHS te kao glavni razlog navode agrarnu reformu. Osim toga žitelji Čađavice navode da je Majlath po osjećaju Mađar, da je na vlastelinstvo namještao Mađare, da je otvarao mađarske škole, a da nije uvažavao „naš narod“. ${ }^{55}$ Kao što smo vidjeli, argumenti žitelja Čađavice ipak nisu u konačnici osporili državljanstvo Kraljevine SHS Ladislavu Mahlathu.

Prethodno izložena analiza upravne prakse u slučajevima ugarskih naseljenika pokazuje određene specifičnosti i bitne razlike u odnosu na stanje do 1918. godine. Naime, do 1918. godine stjecanje zavičajnosti bilo je otežano siromašnim doseljenicima koji često nisu izričito prijavljivali namjeru naseljenja općinskim vlastima te stoga velik broj njih nije stekao hrvatsko-slavonsku zavičajnost. Do toga je dolazilo zbog razlika između hrvatskog i ugarskog sustava pravila o zavičajnosti, poglavito s obzirom na to što je ugarski zakon predvidio relativno liberalan način stjecanja zavičajnosti naseljenjem šutke u pravilu četiri godine od naseljenja, dok hrvatsko-slavonski zakon nije sadržavao takvu mogućnost. ${ }^{56}$ Nesklad hrvatskog i

52 HDA PU HiS OUP, Sv. V-3 5708/1922.

53 O prijavi namjere naseljenja kao nužnoj pretpostavci za stjecanje zavičajnosti naseljenjem vidi: Mutavdjić. op. cit., str. 73.

54 HDA PU HiS OUP, Sv. V-3 5708/1922 (dopis Ministarstva unutrašnjih djela Kraljevine SHS od 3. 11. 1923.).

55 HDA PU HiS OUP, Sv. V-3 5708/1922 (dopis žitelja Čađavice od 1. 6. 1922.).

56 O ugarskom sustavu stjecanja zavičajnosti naseljenjem šutke vidi više u: Žganec, Vinko. Zavičajno pravo u Vojvodini, Međimurju i Prekmurju, Tiskara Vladimir Takšić, Čakovec, 
ugarskog zakona u razdoblju do 1918. godine dovodio je do brojnih rasprava u praksi te do brojnih prepiski između hrvatsko-slavonskih i ugarskih upravnih vlasti. Pritom su u nizu slučajeva hrvatsko-slavonske vlasti negirale stjecanje hrvatsko-slavonske zavičajnosti siromašnim doseljenicima iz Ugarske. ${ }^{57}$ Suprotno tomu, ugarski zavičajnici su bili povlašteni pri zapošljavanju na državnim željeznicama u Hrvatskoj i Slavoniji te su im neovisno o tomu što nisu bili hrvatsko-slavonski zavičajnici davana i neka politička prava u Hrvatskoj i Slavoniji. ${ }^{58}$ Osobito je pak bio pogodan položaj društvene elite doseljene iz Ugarske koja je u Hrvatskoj i Slavoniji do 1918. godine imala značajan ekonomski utjecaj. Nakon 1918. godine situacija se bitno promijenila na način da su ugarski zavičajnici postali strani državljani te stoga nisu više mogli raditi na željeznicama. Od tada su i bogatiji doseljenici iz Ugarske mogli imati problema pri dokazivanju hrvatsko-slavonske zavičajnosti, a onda temeljem toga i državljanstva Kraljevine SHS. Bitno obilježje većine predmeta vođenih nakon 1918. godine bilo je stoga nastojanje mađarskih doseljenika da dokažu stjecanje zavičajnosti u Hrvatskoj i Slavoniji, naročito s obzirom na dužinu boravka te vrlo često inzistiranje hrvatskoslavonskih upravnih vlasti da te osobe nisu stekle hrvatsko-slavonsku zavičajnost u navedenom razdoblju pa tako ni državljanstvo stoga što svoju namjeru naseljenja nisu izričito prijavile općinskim vlastima što je bio conditio sine qua non stjecanja zavičajnosti u Hrvatskoj i Slavoniji do 1918. godine te bitna differentia specifica u odnosu na ugarski sustav zavičajnosti.

Konačno, valja reći da je pored zavičajnosti važan način utvrđivanja državljanstva za određene kategorije osoba moglo biti već spomenuto utvrđivanje državljanstva na temelju Zakona o zaštiti manjina (čl. 6.). Ovdje međutim treba naglasiti da, iako su odredbe Zakona o zaštiti manjina o utvrđivanju državljanstva manjinama na temelju ius soli mogle biti tumačene uključujuće, pregled upravne prakse upućuje na zaključak da utvrđivanje državljanstva temeljem tog članka nije bilo potpuno jednostavno i uspješno za čitav niz osoba te da je Ministarstvo unutrašnjih djela u nizu slučajeva odugovlačilo s priznanjem državljanstva na temelju tog zakona. Tako je, primjerice, usprkos preporuci Velikog župana u Zagrebu Ministarstvo otezalo s priznanjem državljanstva Štefici Racz, nastanjenoj u Zagrebu, te je njenu molbu jednostavno vratilo Velikom županu bez daljnjih uputa, iako je Veliki župan preporučio pozitivno rješenje njene molbe temeljem članka 6 . Zakona o zaštiti manjina. ${ }^{59} \mathrm{U}$ nekim drugim slučajevima Ministarstvo unutrašnjih djela je podnositeljima izrijekom odbilo priznati državljanstvo, iako se radilo o slučajevima koji su se mogli podvesti pod članak 6 . Zakona o zaštiti manjina. Kao primjer možemo navesti predmet Davida Rosnera, Židova nastanjenog u Zagrebu, kojem je Ministarstvo unutrašnjih djela rješenjem donesenim 1928. godine odbilo priznati državljanstvo Kraljevine SHS. Odbijanje

1924., str. 1-13. U Hrvatskoj i Slavoniji je, naime postojala mogućnost stjecanja zavičajnosti naseljenjem, ali samo uz vrlo formalnu izričitu prijavu namjere naseljenja. Usp. čl. 9. i 10. Zakona od 30. travnja 1880. o uređenju zavičajnih odnosa u kraljevinama Hrvatskoj i Slavoniji.

57 Kosnica, Ivan. Hungarians and Citizenship in Croatia-Slavonia 1868-1918, u: David A. Frenkel, Norbert Varga. Law and History, Athens Institute for Education and Research, 2015., str. 65-66.

58 Kosnica. Hungarians (...), op. cit., str. 67.-69. Kosnica. Hrvatsko-slavonska pripadnost (...), op. cit., str. $481 .-482$.

59 HDA ZO VŽ, IV-1, 59733/1926. 
je uslijedilo usprkos preporuci Velikog župana Zagrebačke oblasti i gradskog poglavarstva u Sisku da mu se prizna državljanstvo te činjenicama da se David Rosner rodio 1873. godine u Sisku, da su njegovi roditelji još prije njegovog rođenja doselili u Sisak iz Budimpešte, da je pohađao hrvatske škole te činjenici da mu Budimpeštanske vlasti nisu priznavale zavičajnost. ${ }^{60}$

\section{ZAKON O DRŽAVLJANSTVU IZ 1928. GODINE I PRAVILAO UTVR円IVANJU DR ŽAVLJANSTVA}

Zakon o državljanstvu Kraljevine SHS iz 1928. godine u članku 53. sadržavao je važna pravila za, tzv. početno određenje državljanskog korpusa. ${ }^{61}$ Analizom navedenog članka moguće je u osnovi razlikovati dva skupa početnih državljana na hrvatsko-slavonskom području.

U prvi skup spadaju svi koji su državljanstvo stekli do stupanja Zakona o državljanstvu na snagu. Pobliže govoreći, u ovu skupinu spadaju svi koji su do 1. prosinca 1918. godine bili državljani Kraljevine Hrvatske i Slavonije, ,... a nisu to državljanstvo izgubili na osnovu odredaba ugovora o miru“ (čl. 53. st. 1. toč. 1.), ${ }^{62}$ zatim svi kojima je priznato državljanstvo na temelju ugovora o miru te svi koji su ga stekli opcijom na temelju tih ugovora (čl. 53. st. 1. toč. 2.). U državljane su ubrojeni i svi do tada naturalizirani (čl. 53. st. 1. toč. 3.).

Pored navođenja prethodno navedenih kategorija, izniman doprinos zakona za konsolidaciju državljanskog korpusa ogledao se u tomu što je tim zakonom državljanstvo priznato i određenim kategorijama osoba koje do stupanja na snagu Zakona o državljanstvu Kraljevine SHS nisu mogle biti smatrane za državljane. Riječ je o drugom državljanskom skupu koga su činili brojni podnositelji molbi za naturalizaciju. Zakonom je državljanstvo priznato svim Hrvatima, Srbima i Slovencima koji su podnijeli molbu za stjecanje državljanstva pod pretpostavkom da su punoljetni, ,da su dobrog vladanja“ i ,da mogu uzdržavati sebe i svoju obitelj“ (usp. čl. 53. st. 1. toč. 4.). ${ }^{63}$ Državljanstvo je priznato i svim Slavenima pod pretpostavkom da su podnijeli molbu za naturalizaciju te uz pretpostavku da kontinuirano žive u Kraljevini SHS barem 20 godina (čl. 53. st.1. toč. 5.). Olakotno priznanje državljanstva je uslijedilo i za Slavene koji su zaposleni u državnoj službi ili su od 1. prosinca 1918. godine bili zaposleni u državnoj službi najmanje dvije godine. Tim je osobama priznato državljanstvo Kraljevine SHS uz pretpostavku kontinuiranog prebivališta u Kraljevini u trajanju od barem pet godina (čl. 53. st. 1. toč. 6.). Kao državljani su priznati pod određenim pretpostavkama i svi javni službenici Kraljevine SHS koji su podnijeli molbu za stjecanje državljanstva (čl. 53. st. 1. toč. 7.) ${ }^{64}$ Državljanstvo je priznato i svima koji su podnijeli molbu za stjecanje državljanstva, neovisno o

60 HDA ZO VŽ, IV-1, 19248/1926.

61 Pirkmajer. op. cit., str. 116.

62 Prema Pirkmajeru, odredba o državljanstvu Kraljevine Hrvatske i Slavonije ubačena je u nacrt zakona tek naknadno nakon sporazuma vladine većine i Seljačko-demokratske koalicije. Ibid., str. 117.

63 Kod ove kategorije osoba nije se tražio dokaz prebivanja na teritoriju Kraljevine.

64 Ibid., str. 123. 
etničkom kriteriju, ako su trideset godina prebivali na teritoriju Kraljevine SHS i pod pretpostavkom da deset godina prije podnošenja molbe nisu ispunjavali nikakve obveze prema prijašnjoj domovini (čl. 53. st. 1. toč. 8.). Ako su prethodno navedene osobe imale obitelj, kao državljani su priznati i članovi njihovi obitelji (čl. 53. st. 1. toč. 9.). Konačno, Zakon o državljanstvu je u članku 53. st. 1. točki 10. sadržavao i kriterij ius soli kao osnovu za utvrđivanje državljanstva osoba rođenih u Kraljevini, ako je njihovo državljanstvo nepoznato.$^{65}$ Osobe navedene pod točkama 4. do 8. članka 53. Zakona o državljanstvu trebale su u roku od godine dana od stupanja na snagu Zakona o državljanstvu, dakle počevši od 1. studenoga 1928. godine, podnijeti odgovarajući zahtjev sreskim upravnim vlastima, dok je rješenje o priznanju državljanstva donosio veliki župan. ${ }^{66}$ Nakon upravne reorganizacije Kraljevine 1929. godine te osnivanja banovina, umjesto ukinutih velikih župana, uprave pojedinih banovina bile su nadležne utvrđivati državljanstvo, dok je vrhovnu vlast i dalje imalo Ministarstvo unutrašnjih djela u Beogradu.

Ključna razlika u odnosu na stanje do donošenja Zakona o državljanstvu ogledala se u činjenici da je od stupanja na snagu Zakona o državljanstvu proširen broj situacija u kojima je moglo biti jednostavno utvrđeno državljanstvo Kraljevine SHS, odnosno od 1929. godine Kraljevine Jugoslavije. Zakon je omogućio da pored već spomenutog utvrđivanja državljanstva pomoću zavičajnosti, a sve na temelju mirovnih ugovora te pored spomenutog utvrđivanja državljanstva na temelju Zakona o zaštiti manjina primjenom ius soli, u čitavom nizu slučajeva deklaratornim aktom bude utvrđeno državljanstvo Kraljevine SHS. Pritom je osnovna pretpostavka za priznanje državljanstva bilo podnošenje molbe za naturalizaciju. Iz teksta zakona vidljivo je da su u čitavom procesu favorizirani Hrvati, Srbi, Slovenci, a također u određenoj mjeri i ostali Slaveni. Pored etničkoga kriterija, zakonom je neovisno o etničkom kriteriju državljanstvo priznato tek javnim službenicima koji su se s obzirom na obnašanje javne službe mogli smatrati pouzdanima i lojalnima te osobama koje su, s obzirom na tridesetogodišnju prisutnost na teritoriju Kraljevine SHS, mogle biti smatrane dovoljno integriranima u društvo.

Zakonom o državljanstvu iz 1928. godine promijenjena je pravna priroda nekih predmeta o državljanstvu na način da su predmeti stjecanja državljanstva, ako su bile ispunjene zakonske pretpostavke, postali predmeti utvrđivanja državljanstva. Ilustrativan je u tom smislu slučaj Antuna Klimana, istarskog emigranta u Zagrebu koji je do stupanja na snagu Zakona o državljanstvu Kraljevine SHS 1. studenoga 1928. godine bio strani talijanski državljanin te ujedno podnositelj molbe za stjecanje

65 Pirkmajer, op. cit., str. 113.-126. i str. 212.-222. Cavalieri, Celso. Propisi o državljanstvu Kraljevine Srba, Hrvata i Slovenaca, Vlastita naklada, Zagreb, 1929., str. 101.-111. Kavaljeri, Celzije. Komentar Zakona o državljanstvu Kraljevine Jugoslavije, Vlastita naklada, Zagreb, 1935., op. cit., str. 127.-141.

66 U slučaju odbijanja zahtjeva za priznanjem državljanstva, nezadovoljna stranka je mogla uložiti žalbu na Ministarstvo unutrašnjih dijela (usp. čl. 53. st. 2. Zakona o državljanstvu Kraljevine SHS). Vidi i čl. 77. Uredbe za izvršenje Zakona o državljanstvu Kraljevine SHS. Tekst uredbe vidi u: Ivanda, Stipe. Zbirka propisa o državljanstvu hrvatskomu, VIV Inženjering, Zagreb, 1995., str. 182.-213. Tepić, Đuro i Bašić, Ivan. Zbirka propisa o državljanstvu, Narodne novine, Zagreb, 1969., str. 131.-177. 
državljanstva Kraljevine SHS. Međutim, od stupanja na snagu Zakona o državljanstvu Kraljevine SHS njegovu molbu nije više razmatrao ministar unutrašnjih poslova nego je predmet bio ovlašten konačno riješiti veliki župan Zagrebačke oblasti, na način da je pozivajući se na članak 53. Zakona o državljanstvu utvrdio da je Antun Kliman, podnositelj molbe za naturalizaciju te podrijetlom i jezikom Hrvat ujedno i državljanin Kraljevine SHS. Slijedom navedenoga, Veliki župan je naredio policijskoj upravi u Zagrebu da mu izda potvrdu o državljanstvu. ${ }^{67}$

Iako je člankom 53. Zakona o državljanstvu bitno proširen državljanski korpus te je stvorena pravna osnova za rješavanje čitavog niza pitanja utvrđivanja državljanstva u sklopu nadležnosti velikih župana, rasterećujući tako Ministarstvo unutrašnjih djela u Beogradu, Zakon ipak nije u potpunosti riješio probleme u upravnoj praksi. Zbog toga, kako bi pospješila rješavanje predmeta utvrđivanja državljanstva, intervenirala je kasnije i Banska vlada Banovine Hrvatske, i to tako da je izdala upute o utvrđivanju državljanstva. ${ }^{6}$ Upute su klasificirane kao povjerljive, a sastavio ih je podban Ivo Krbek 29. srpnja 1940. godine. Upute utvrđuju postojanje niza slučajeva u praksi u kojima je prisutan spor o državljanstvu osoba koje su, kako stoji u tekstu uputa, "od rođenja ili više desetljeća stalno nastanjene na teritoriji Banovine Hrvatske". Uputama se konstatira da se tim osobama "prave nepotrebne teškoće i da se te osobe upućuju na podnošenje kompliciranih molbi iako bi im se temeljem zakonskih propisa imalo samo utvrditi da su stekli pravo odnosno da su naši državljani”. Osim načelne konstatacije o postojanju sporova, upute izrijekom navode i grupu državljana koji su temeljem mirovnog ugovora potpisanog u Saint Germainu 1919. godine, stekle državljanstvo Kraljevine SHS što se dodatno potkrepljuje pozivanjem na članak 53. točku 2. Zakona o državljanstvu. U tim slučajevima, prema uputama Banske vlade nadležne upravne vlasti su trebale priznati državljanstvo "bez ikakvih formalnosti". Pritom je predviđeno favoriziranje Hrvata, Srba i Slovenaca te "Slavena u obzira vrijednim slučajevima”. U takvim slučajevima nadležna upravna tijela trebala su postupati po službenoj dužnosti te su molbe za utvrđivanje državljanstva trebale podnijeti Banskoj vladi. Molbi je podnositelj trebao priložiti krsne listove za sebe i oca, uvjerenje o zajamčenom prijemu u zavičajnost te potvrdu nadležne općine kojom se potvrđivalo moralno vladanje, mogućnost uzdržavanja te vrijeme boravka na teritoriju države i narodnost. Po rješenju Banske vlade nadležna upravna tijela bila su ovlaštena izdati potvrdu o državljanstvu. ${ }^{69}$

Navedene upute o utvrđivanju državljanstva upućuju na namjeru Banske vlade da riješi nesređena pitanja u pogledu državljanstva određenog broja osoba koje su dulje vrijeme prisutne na teritoriju Banovine Hrvatske i koje su se po svojoj prilici asimilirale. Osobito je u tom smislu indikativno da su upute usmjerene ponajprije na Hrvate, Srbe, Slovence i "ostale obzira vrijedne Slavene", što čitavom postupku

67 HDA ZO VŽ, IV-1, 63467/26.

68 Nakon reforme unutrašnjeg uređenja države 1939. godine, osnivanjem Banovine Hrvatske, Banovni je dana značajna nadležnost u pitanjima državljanstva što je uključivalo i punu nadležnost u postupcima utvrđivanja državljanstva. Usp. čl. 2. Uredbe o Banovini Hrvatskoj, Službene novine, br. 194 A-LXVIII, 26. kolovoza 1939.

69 HR HDA Banovina Hrvatska, Odjel za unutarnje poslove, fond 157 (u nastavku: HDA BHOUP-157), kutija 3, pov. I-3 690/1940. 
utvrđivanja državljanstva daje snažan etnički karakter.

\section{ZAKLJUČAK}

Provedeno istraživanje problematike temeljnog određenja državljanskog korpusa upućuje nas na zaključak da je odmah po formiranju Kraljevine SHS na hrvatsko-slavonskom području prihvaćen model definiranja državljanskoga korpusa na temelju zavičajnosti u nekoj o hrvatsko-slavonskih općina. Bitna razlika ovog modela u usporedbi s modelom primjenjivanim do 1918. godine bila je u napuštanju presumpcije ius soli. U praksi je inzistiranje na zavičajnosti dovelo do toga da je čitavom nizu doseljenika iz Ugarske negirano državljanstvo. To je bilo moguće zbog toga što je hrvatsko-slavonska zavičajnost bila relativno zatvoren koncept te ju zbog izrazito formalnih načina stjecanja nije stekao relativno velik broj doseljenika.

Bitne promjene kojima je dodatno sužen državljanski korpus provedene su mirovnim ugovorima, od kojih je za hrvatsko-slavonsko pravno područje važan mirovni ugovor s Ugarskom. Mirovni ugovori definirali su, tzv. početan državljanski korpus na temelju zavičajnosti te su se po tome nastavljali na dotadašnji model utvrđivanja državljanstva. Značajna je razlika u usporedbi s prethodnim stanjem u tomu što je prema mirovnim ugovorima relevantna bila samo zavičajnost stečena do 1. siječnja 1910. godine uz dodatnu pretpostavku da ju je osoba zadržala do trenutka kad je mirovni ugovor stupio na snagu. Ovo pravilo u osnovi je redefiniralo značaj zavičajnosti kao osnove utvrđivanja državljanstva te je iz državljanskog korpusa isključilo sve koji su stekli zavičajnost u Hrvatskoj i Slavoniji nakon 1. siječnja 1910. godine, odnosno one koji ju nisu uspjeli zadržati do stupanja mirovnih ugovora na snagu. Restriktivnost sustava trebala je biti ublažena tek odredbom Zakona o zaštiti manjina kojom su kao državljani trebali biti priznati i svi rođeni u zemlji, pod pretpostavkom da ,se ne mogu pozvati ni na koje drugo državljanstvo po rođenju“.

Relativizacija značaja zavičajnosti provedena mirovnim ugovorima imala je za daljnju posljedicu uvođenje novih potvrda o državljanstvu odnosno odgovarajućih klauzula o državljanstvu izdavanih po upravnim vlastima. Odmak od uključujuće presumpcije ius soli te činjenica da je hrvatski sustav stjecanja zavičajnosti bio vrlo zatvoren omogućili su vlastima Kraljevine SHS da smjerom, koji se mogao nazrijeti i prije stupanja mirovnih ugovora na snagu u nizu slučajeva, negiraju državljanstvo osobama, u velikoj mjeri doseljenicima iz Ugarske koji su u Hrvatskoj i Slavoniji živjeli i više desetljeća, a od kojih su neki i rođeni u Hrvatskoj i Slavoniji prije pedeset godina. Restriktivnost sustava nije ublažio ni Zakon o zaštiti manjina, budući da u brojnim slučajevima pojedinci nisu uspjeli ostvariti priznanje državljanstva na temelju tog zakona.

Do bitnog proširenja državljanskoga korpusa došlo je tek 1928. godine stupanjem na snagu Zakona o državljanstvu. Navedeni propis je osim spominjanja već ranije priznatih državljana, sadržavao i niz drugih kriterija primjenom kojih je omogućeno šire početno određenje državljanskoga korpusa. Pritom je primjetno da je Zakon o državljanstvu kao državljane priznao Hrvate, Srbe i Slovence koji su podnijeli molbu za stjecanje državljanstva. Odstupanje od etničkog kriterija bilo je 
načelo ius soli, primjenom kojeg su kao državljani trebali biti priznati i svi rođeni na teritoriju Kraljevine, ako im je državljanstvo bilo nepoznato. Etnički neutralna odredba bila je i odredba o tomu da su državljani svi koji su podnijeli molbu za stjecanje državljanstva ako ispunjavaju zakonske pretpostavke među kojima je bila ključna pretpostavka tridesetogodišnjeg boravka na teritoriju Kraljevine. Primjena zakona u praksi pokazuje da su državne vlasti favorizirale vođenje postupaka $\mathrm{u}$ kojima je utvrđivano državljanstvo Srba, Hrvata i Slovenaca te u određenoj mjeri i drugih Slavena. Ostalim etničkim grupama ostavljena je relativno uska mogućnost za priznavanje državljanstva te su one u konačnici mogle pokušati steći državljanstvo u postupku naturalizacije.

\section{LITERATURA}

Arhivska građa:

1. HR Hrvatski državni arhiv, Pokrajinska uprava za Hrvatsku i Slavoniju u Zagrebu, Odjeljenje za unutarnje poslove

2. HR Hrvatski državni arhiv, Zagrebačka oblast, Veliki župan, fond 141

3. HR Hrvatski državni arhiv, Savska banovina, upravno odjeljenje, fond 144

4. HR Hrvatski državni arhiv, Banovina Hrvatska, Odjel za unutarnje poslove, fond 157

5. HR Hrvatski državni arhiv, Zbirka personalija Banovine Hrvatske, fond 890

Pravni propisi:

1. Naredba predsjedništva Narodnog Vijeća Slovenaca, Hrvata i Srba od 12. studenoga 1918. br. 33443, Zbornik zakona i naredaba valjanih za Hrvatsku i Slavoniju, komad XVI, 1918.

2. Narodne novine, br. 9., 13. siječnja 1919., Zagreb

3. Narodne novine, br. 23., 29. siječnja 1919., Zagreb

4. Narodne novine, br. 25., 31. siječnja 1919., Zagreb

5. Narodne novine, br. 27., 3. veljače 1919., Zagreb

6. Uredba o Banovini Hrvatskoj, Službene novine, br. 194 A-LXVIII, 26. kolovoza 1939.

7. Uredba o izboru gradskih zastupstva za gradove Hrvatske i Slavonije, u: Zbornik zakona i naredaba valjanih za Hrvatsku i Slavoniju, godina 1919., Kr. zemaljska tiskara, Zagreb, 1920., str. 267-271.

8. Uredba o izboru općinskih odbora za upravne općine Hrvatske i Slavonije, u: Zbornik zakona i naredaba valjanih za Hrvatsku i Slavoniju, godina 1919., Kr. zemaljska tiskara, Zagreb, 1920., str. 274-280.

9. Ustav Kraljevine Srba, Hrvata i Slovenaca, obnarodovan u br. 142a „Službenih novina“ na Vidovdan 28. juna 1921. god. u Beogradu, Državna štamparija Kraljevine Srba, Hrvata i Slovenaca, Beograd, 1926.

10. Ustav Kraljevine Jugoslavije, obnarodovan u „Službenim novinama“ 3. rujna 1931., Tisak i naklada knjižare St. Kugli, Zagreb, 1931.

11. Zakonski članak L.:1879. zajedničkoga hrvatsko-ugarskoga sabora o stečenju i gubitku ugarskoga državljanstva, u: Sbornik zakonah i naredabah valjanih za kraljevinu Hrvatsku i Slavoniju, komad VII., 1880.

12. Zakon o državljanstvu Kraljevine Srba, Hrvata i Slovenaca, Službene novine, broj 254/1928.

13. Zakon od 30. travnja 1880. o uređenju zavičajnih odnosa u kraljevinama Hrvatskoj i Slavoniji, Sbornik zakonah i naredabah valjanih za Kraljevinu Hrvatsku i Slavoniju, komad IX., 1880. 
Knjige i članci:

1. Andrassy, Juraj. Novo ustavno uređenje Hrvatske, Mjesečnik: glasilo hrvatskoga pravničkoga društva, Zagreb, 1940., str. 226.-239.

2. Bartulović, Željko. Sušak 1919.-1947.: Državnopravni položaj grada, Pravni fakultet Sveučilišta u Rijeci, Državni arhiv u Rijeci, Adamić, Rijeka, 2004.

3. Beuc, Ivan. Povijest institucija državne vlasti u Hrvatskoj (1927-1945), Arhiv Hrvatske, Zagreb, 1969.

4. Cavalieri, Celso. Propisi o činovnicima i ostalim državnim službenicima građanskog reda, Vlastita naklada, Zagreb, 1926.

5. Cavalieri, Celso. Propisi o državljanstvu Kraljevine Srba, Hrvata i Slovenaca, Vlastita naklada, Zagreb, 1929.

6. Cavalieri, Celzije. Tumač zakona o činovnicima s naročitim osvrtom na zakon o državnom saobraćajnom osoblju, Vlastita naklada, Zagreb 1931.

7. Čepulo, Dalibor. Prava građana i moderne institucije: Europska i hrvatska pravna tradicija, Pravni fakultet Sveučilišta u Zagrebu, Zagreb, 2003.

8. Čepulo, Dalibor. Pravo hrvatske zavičajnosti i pitanje hrvatskog i ugarskog državljanstva 1868-1918 - pravni i politički vidovi i poredbena motrišta, Zbornik Pravnog fakulteta $u$ Zagrebu, vol. 49 (1999), br. 6., str. 795.-825.

9. Dobrovšak, Ljiljana. Zaposlenici na željeznicama u Hrvatskoj 1903. godine, Časopis za suvremenu povijest, vol. 40 (2008), br. 2., str. 489.-516.

10. Engelsfeld, Neda. Povijest hrvatske države i prava: razdoblje od 18. do 20. stoljeća, Pravni fakultet, Zagreb, 1999.

11. Engelsfeld, Neda. Prvi parlament Kraljevstva Srba, Hrvata i Slovenaca - Privremeno narodno predstavništvo, Globus, Zagreb, 1989.

12. Fahrmeir, Andreas. Citizenship: The Rise and Fall of a Modern Concept, Yale University Press, New Haven and London, 2007.

13. Fink, Carole. The Paris Peace Conference and the Question of Minority Rights, Peace \& Change, Vol. 21. (1996), br. 3., str. 273.-288.

14. Goldstein, Ivo. Hrvatska 1918.-2008., EPH Liber, Zagreb, 2008.

15. Ivanda, Stipe. Zbirka propisa o državljanstvu hrvatskomu, VIV Inženjering, Zagreb, 1995.

16. Kavaljeri, Celzije. Komentar Zakona o državljanstvu Kraljevine Jugoslavije, Vlastita naklada, Zagreb, 1935.

17. Kosnica, Ivan. Citizenship in Croatia-Slavonia during the First World War, Journal on European History of Law, 8 (2017), 1, str. 58.-65.

18. Kosnica, Ivan. Hrvatsko-slavonska pripadnost u Hrvatskoj i Slavoniji u nagodbenom razdoblju, Hrvatska i komparativna javna uprava - Croatian and Comparative Public Administration, vol. 14. (2014), br. 2., str. 465.-492.

19. Kosnica, Ivan. Hungarians and Citizenship in Croatia-Slavonia 1868-1918, u: David A. Frenkel, Norbert Varga

20. Kosnica, Ivan. Utvrđivanje državljanstva u Hrvatskoj i Slavoniji 1849. - 1880., Zbornik radova Pravnog fakulteta $u$ Splitu, god. 51., 3/2014, str. 697.-713.

21. Law and History, Athens Institute for Education and Research, 2015., str. 59-72.

22. Lucassen, Leo. Between Hobbes and Locke. Gypsies and the limits of the modernization paradigm, Social History, vol. 33 (2008), br. 4., str. 423.-441.

23. Mazur Kumrić, Nives. Europski sustav zaštite prava manjina uz poseban osvrt na Vijeće Europe i Organizaciju za sigurnost i suradnju u Europi, Školska knjiga, Zagreb, 2017.

24. Motta, Giuseppe. Less than Nations: Central-Eastern European Minorities after WWI, Volume I, Cambridge Scholars Publishing, Newcastle upon Tyne, 2013.

25. Mutavdjić, Koloman. Zavičajno pravo: Zakon od 30. travnja 1880. ob uređenju zavičajnih odnošaja u kraljevinah Hrvatskoj $i$ Slavoniji i prijašnji propisi o stečenju i gubitku zavičajnoga prava, Naklada knjižare Lav. Hartmana (Kugli i Deutsch), Zagreb, 1894. 
26. Omejec, Jasna. Initial Citizenry of the Republic of Croatia at the Time of the Dissolution of Legal Ties with the SFRY, and Acquisition and Termination of Croatian Citizenship, Croatian Critical Law Review, vol. 3 (1998), br. 1-2., str. 99-127.

27. Pirkmajer, Otomar. Zakon o državljanstvu sa tumačenjem, Izdavačka knjižara Gece Kona, Beograd, 1929.

28. Polić, Ladislav. O pravnim osnovima budućeg izbornoga reda, Mjesečnik: glasilo pravničkoga društva, br. 2., 1922., str. 49.-63.

29. Polić, Ladislav. Pitanje državljanstva, u: Dolenc, Metod i Sajovic, Rudolf. Spomenica na Drugi kongres pravnika Kraljevine Srba, Hrvata i Slovenaca u Ljubljani od 9. do 11. septembra 1926. godine, Društvo „Pravnik“ u Ljubljani, Ljubljana, 1927., str. 209.-216.

30. Riga, Liliana i Kennedy James. Tolerant majorities, loyal minorities and „ethnic reversals“: constructing minority rights at Versailles 1919, Nations and Nationalism, vol. 15. (2009), br. 3., str. 461.-482.

31. Štiks, Igor. Nations and Citizens in Yugoslavia and the Post-Yugoslav States: One Hundred Years of Citizenship, Bloomsbury Academic, London-New York, 2015.

32. Tepić, Đuro i Bašić, Ivan. Zbirka propisa o državljanstvu, Narodne novine, Zagreb, 1969.

33. Varga, Norbert. The Framing of the First Hungarian Citizenship Law (Act 50 of 1879) and the Acquisition of Citizenship, Hungarian Studies, vol. 18 (2004), br. 2., str. 127.-151.

34. Vukas, Budislav. Etničke manjine i međunarodni odnosi, Školska knjiga, Zagreb, 1978.

35. Žganec, Vinko. Zavičajno pravo u Vojvodini, Međimurju i Prekmurju, Tiskara Vladimir Takšić, Čakovec, 1924. 


\title{
Ivan Kosnica*
}

\author{
Summary
}

\section{DEFINING CITIZENS IN THE KINGDOM OF SHS YUGOSLAVIA (1918-1941): THE CASE OF CROATIAN- SLAVONIAN AREA}

The paper deals with initial definition of citizenry on Croatian-Slavonian area in the First Yugoslavia. The research relies in great measure on archival research available in the Croatian National Archive. In the paper, the author elaborates few theses. The first one is about local citizenship as fundamental criteria for determination of citizenship in the first years of the Kingdom of Serbs, Croats and Slovenes. Further, the author elaborates thesis about peace treaties as a crucial moment that negated relevance of local citizenship for determination of national citizenship if acquired after January 1 of 1910. The author argues that this rule as well as initially restrictive rules about local citizenship enabled administrative authorities of the First Yugoslavia to question national citizenship of many persons, especially ones who moved in Croatia-Slavonia from Hungary. According to the author, the authorities significantly widened citizen's body in 1928 when the law about citizenship of the Kingdom of Serbs, Croats and Slovenes entered into force. This inclusion however in great measure favored ethnic Serbs, Croats and Slovenes.

Keywords: determination, national citizenship, local citizenship, CroatianSlavonian legal area, the Kingdom of Serbs, Croats and Slovenes, the Kingdom of Yugoslavia.

Zussamenfassung

\section{BESTIMMUNG DES STAATSVOLKES IM KROATISCH- SLAWONISCHEN GEBIET DES SHS-KÖNIGREICHS/DES KÖNIGREICHS JUGOSLAWIEN}

Die Arbeit bespricht die sog. ursprüngliche Bestimmung des Staatsvolkes im kroatisch-slawonischen Gebiet des SHS-Königreichs/des Königreichs Jugoslawien. Mangels relevanter Forschung über die genannte Problematik wurde eine sehr umfangreiche Archivforschung im Kroatischen Staatsarchiv durchgeführt. Aufgrund dieser Forschung werden in der Arbeit einige Thesen dargestellt. Die

* Ivan Kosnica, Ph. D., Assistant Professor, Faculty of Law, University of Zagreb; ivan.kosnica@ pravo.hr. 
erste These schlägt vor, dass gleich nach der Formierung des SHS-Königreichs das System herrschte, gemä $\beta$ welchem alle Domizilanten der kroatisch-slawonischer Gemeinden die Staatsangehörigkeit besaßen. Anschließend wird argumentiert, dass die Friedensverträge das bis zum damaligen Zeitpunkt geltende System der Bestimmung von Staatsangehörigen wesentlich geändert haben, indem sie die Wichtigkeit des Domizils für die Feststellung der Staatsangehörigkeit negiert haben, falls dieser nach 1. Januar 1910 erlangt wurde. Es wird auch die These vertreten, dass die Bestimmungen der Friedensverträge sowie auch das restriktive System der Erlangung des Domizils, welches kennzeichnend für Kroatien und Slawonien im Zeitraum bis 1918 war, den Behörden des SHS-Königreichs ermöglicht haben, die gewünschten Staatsangehörigen auszuwählen und einer bestimmten Zahl der Zuwanderer aus Ungarn die Staatsangehörigkeit zu verweigern. Weiterhin wird in der Arbeit festgestellt, dass die Stabilisierung des Systems und die breitere Definition des Staatsvolkes erst durch das Inkrafttreten des Gesetzes über Staatsangehörigkeit 1928 entstanden sind, wobei man dabei besonderen Wert auf die Anwendung ethnischer Kriterien gelegt hat.

Schlüsselwörter: Feststellung, Staatsangehörigkeit, kroatisch-slawonisches Gebiet, SHS-Königreich, Königreich Jugoslawien.

Riassunto

\section{LA DEFINIZIONE DI CITTADINANZA NELLA PRIMA JUGOSLAVIA (1918-1941): IL CASO DELL'AREA CROATO- SLAVONE}

L'oggetto del lavoro è rappresentato dalla c.d. determinazione iniziale della cittadinanza sul territorio croato-slavone nella Prima Jugoslavia. Vista la evidente mancanza di ricerche rilevanti su detta questione, l'autore ha condotto una ricerca d'archivio molto dettagliata circa la documentazione d'archivio accessibile nell'Archivio di Stato croato. In base alla ricerca condotta l'autore espone alcune tesi. La prima tesi è che subito all'atto della creazione del Regno dei Serbi, Croati e Sloveni valeva il sistema in base al quale erano cittadini tutti gli autoctoni dei comuni croatoslavoni. Nel prosieguo del lavoro l'autore argomenta la tesi secondo la quale i trattati di pace avrebbero modificato in maniera significativa il sistema di determinazione della cittadinanza precedente, visto che negavano rilevanza all'autoctonia al fine dell'accertamento della cittadinanza in quanto fosse stata conseguita dopo il 1 . gennaio dell'anno 1910. La tesi dell'autore è che le disposizioni dei trattati di pace, come pure il sistema restrittivo di acquisto della cittadinanza in base all'autoctonia, il quale era caratteristiche per la Croazia e la Slavonia nel periodo fino al 1918, abbiano permesso alle autorità del Regno dei Serbi, Croati e Sloveni di operare una certa selezione dei cittadini idonei e la negazione della cittadinanza ad un certo numero di immigrati 
dall'Ungheria. Ancora, l'autore valuta che una certa stabilizzazione del sistema, come anche una più ampia determinazione della cittadinanza, siano stati raggiunti appena con la legge sulla cittadinanza del 1928, benché sottolineando l'applicazione del criterio etnico.

Parole chiave: accertamento, cittadinanza, territorio croato-slavone, Regno dei Serbi, Croati e Sloveni, Regno di Jugoslavia. 